\title{
HEAVY METAL CADMIUM (Cd) AND LEAD (Pb) IN VANAME SHRIMP (Litopenaeus vannamei) COLLECTED FROM TRADITIONAL MARKETS IN MEDAN CITY, INDONESIA
}

\author{
Eri Yusni $^{1}$. Tri Pardiana Setiani ${ }^{1}$.
}

Ringkasan The presence of heavy metals in the aquatic environment must be monitored continuously. This study aims to determine the amount of heavy metal content of Cadmium $(\mathrm{Cd})$ and Lead $(\mathrm{Pb})$ on Vaname Shrimp (Litopenaeus vannamei). Determining the value of Cadmium $(\mathrm{Cd})$ and Lead $(\mathrm{Pb})$ using an AAS (Atomic Absorption Spectrophotometer) device. It is known that the highest $C d$ content in the sample 4 (market pancing) which is worth 0.011 $m g / k g$, and the lowest is in the sample 6 (market sei kambing) which is worth $0.004 \mathrm{mg} / \mathrm{kg}$. The value of the highest $\mathrm{Pb}$ value is found in the sample 3 (market merah) worth 0.019 and the lowest value is the sample 5 (market petisah) worth 0.008. So that the results of these tests can be concluded, that the content of heavy metals $\mathrm{Cd}$ and $\mathrm{Pb}$ in each sample of vaname shrimp is classified as low according to the World Health Organization (WHO), namely the maximum limit of $C d$ is 5.0 and the maximum limit of $\mathrm{Pb}$ is 2.0 while according to EUROPEAN UNION the limit of calcium $C d$ is 0.2 and the maximum

\footnotetext{
${ }^{1}$ )Fakultas Pertanian, Universitas Sumatera Utara, Indonesia Medan

E-mail: eriyusni@hotmail.com
}

limit of $\mathrm{Pb}$ is 0.5 because the vaname shrimp sample is still safe for consumption and can be an export commodity.

Keywords Cadmium, Lead, Vanammae, Traditional market, Medan

Received : 13 Januari 2019

Accepted :14 Maret 2019

\section{PENDAHULUAN}

Keberadaan logam berat di perairan telah lama diketahui dapat memberikan dampak negatif bagi kehidupan organisme. Keberadaan logam berat pada perairan tidak lepas dari kegiatan manusia. Sumber utama pemasukan logam berat berasal dari pertambangan, cairan limbah rumah tangga dan limbah buangan industri serta aliran dari pertanian (Supriadi, 2016). Timbal (Pb) dan Kadmium (Cd) merupakan logam berat yang banyak mencemari lingkungan perairan.

Logam Timbal $(\mathrm{Pb})$ merupakan logam yang sangat populer dan banyak dikenal oleh masyarakat awam. Hal ini disebabkan oleh banyaknya $\mathrm{Pb}$ yang di- 
gunakan di industri non pangan. Industri yang berpotensi sebagai sumber pencemaran $\mathrm{Pb}$ adalah semua industri yang memakai $\mathrm{Pb}$ sebagai bahan baku maupun bahan penolong (Pardi et al., 2014). $\mathrm{Pb}$ dapat menyebabkan keracunan pada makhluk hidup dan merupakan zat yang terbukti mampu menekan sistem imun. Sistem imun yang tidak berfungsi dengan baik akan memperbesar kerentanan tubuh terhadap bakteri, parasit, dan virus serta kerentanan terhadap kanker (Widyastuti, 2002). Logam $\mathrm{Pb}$ dapat masuk ke dalam tubuh manusia melalui pernapasan, makanan, dan minuman. Bila makanan tercemar oleh logam tersebut, tubuh akan mengeluarkannya sebagian. Sisanya akan terakumulasi pada bagian tubuh tertentu seperti ginjal, hati, kuku, jaringan lemak dan rambut.

Logam berat lainnya yang sering ditemukan dalam limbah industri adalah logam berat Kadmium (Cd). Logam berat berbahaya yang terakumulasi pada biota laut terserap melalui insang dan saluran pencernaan. Logam berat $\mathrm{Cd}$ yang tertimbun dalam jaringan dan berikatan dengan protein disebut dengan metalotionein (MTN), bersifat agak permanen dan mempunyai waktu paruh yang cukup lama. Cd merupakan logam berat yang memiliki toksisitas yang tinggi setelah $\mathrm{Hg}$. Level maksimum Cd dalam air limbah yang diperbolehkan berdasarkan Keputusan Menteri Negara Lingkungan Hidup Nomor: KEP-51 / MENLH / 10 / 1995 tentang Baku Mutu Limbah Cair Bagi Kegiatan Industri adalah sebesar $0.05 \mathrm{ppm}$.

$\mathrm{Cd}$ termasuk logam berat tidak esensial, yakni logam yang keberadaannya dalam tubuh masih belum diketahui manfaatnya bahkan bersifat toksik. Kebe- radaan logam $\mathrm{Cd}$ dalam perairan perlu diketahui secara pasti sebab kadar yang terlalu tinggi dapat berdampak buruk bagi kesehatan (Sasongko et al., 2017). Kadmium (Cd), dapat mengakibatkan timbulnya penyakit mental dan kelainan syaraf pada penduduk yang hidup di sekitar Teluk Minamata di Jepang. Toksisitas yang dikandung oleh logam cadmium tersebut juga mengakibatkan terjadinya kerapuhan pada tulang penderita (Palar, 1994).

Logam berat berdampak buruk bagi ekosistem perairan. Salah satu organisme yang akan terkena dampak pencemaran logam berat adalah udang. Analisis kandungan logam berat pada biota seperti udang perlu dilakukan, hal ini disebabkan kandungan logam berat dalam air yang dapat berubah-ubah dan bergantung pada lingkungan. Pada musim hujan kandungan logam di perairan akan lebih kecil karena proses pelarutan, sedangkan pada musim kemarau kandungan logam akan lebih tinggi karena logam menjadi terkonsentrasi. Kandungan logam berat pada biota air biasanya selalu bertambah dari waktu kewaktu karena sifat logam yang bioakumulatif, sehingga biota air sangat baik digunakan sebagai indikator pencemaran logam dalam lingkungan perairan (Widyastuti, 2002).

Udang (Crustacea) dapat mengakumulasi logam berat yang terlarut dalam air maupun yang terendap di sedimen sungai (Darmono, 2006). Paparan Timbal dapat mengakibatkan perubahan tingkah laku dan fisiologi pada udang. Logam berat tersebut sebagian akan terendapkan di dasar perairan. Sebagian akan terakumulasi di dalam tubuh biota laut melalui rantai makanan. Biota laut jenis krustasea yaitu udang dan 
rajungan sering dijadikan bioindikator pencemaran logam berat di laut karena jenis organisme seperti krustase relatif tidak secepat ikan dalam menghindar dari pengaruh polusi logam dalam air (Darmono, 2006).

Jenis makanan udang sangat bervariasi tergantung pada tingkatan stadium. Pada stadium benih, makanan utamanya adalah plankton (fitoplankton dan zooplankton). Udang dewasa menyukai daging binatang lunak atau moluska (kerang, tiram, siput), cacing, annelida dan crustacea. Pada kegiatan usaha budidaya, udang mendapatkan makanan alami yang tumbuh di tambak, yaitu lumut, plankton, dan bentos. Udang akan bersifat kanibal bila kekurangan makanan (Octavianus et al., 2017). Sifat krustasea yang mencari makan pada dasar perairan, yaitu pada lingkungan sedimen akan menyebabkan krustasea sangat mungkin terkontaminasi. Sebagian besar logam berat timbal masuk ke dalam hewan laut melalui rantai makanan dan hanya sedikit yang langsung diambil dari air (Widajanti et al., 2004). Tumisem and Puspawiningtiyas (2011), menyatakan bahwa akumulasi logam berat di dasar perairan dimungkinkan untuk masuk ke dalam rangkaian rantai makanan. Konsentrasi logam di biota laut akan terus meningkat apabila terjadi proses biomagnifikasi (Salbiah et al., 2009).

Udang memiliki harga jual yang tinggi sehingga dapat menguntungkan para nelayan. Rasa yang enak menjadikan jenis udang dikonsumsi masyarakat secara luas (Tumisem and Puspawiningtiyas, 2011). Hal ini dapat memungkinkan masyarakat mengonsumsi udang terpapar Timbal. Konsumsi udang yang terpapar logam berat Timbal dapat meng- ganggu kesehatan. Pengaruh Timbal bagi anak-anak adalah menurunnya kemampuan belajar, hiperaktif dan mengganggu pertumbuhan. Pada orang dewasa yang terpapar Timbal dapat mengalami kerusakan saraf, ginjal dan dapat menyebabkan kematian. Penelitian ini penting dilakukan untuk mengetahui kadar Timbal $(\mathrm{Pb})$ dan Kadmium (Cd) pada jenis udang vaname yang dijual di lingkungan pasar.

\section{MATERI DAN METODE}

Sampel udang dikumpulkan dari 6 pasar. Sampel 1 (Pasar Padang Bulan), Sampel 2 (Pasar Belawan), Sampel 3 (Pasar Merah), Sampel 4 (Pasar Pancing), Sampel 5 (Pasar Petisah) dan Sampel 6 (Pasar Sei Sekambing). Penelitian dilakukan pada bulan Juni hingga September 2018. Sampel yang dikumpulkan disimpan dalam kotak es kemudian dibawa ke Laboratorium Zoologi, Universitas Sumatera Utara, Medan untuk analisis lebih lanjut. Persiapan sampel mengacu pada BSN (2001).

Metode yang digunakan dalam pengujian ini seauai dengan SNI 2354.5:2011 (BSN, 2001)adalah metode graphite furnace dengan alat AAS (Atomic Absorption Spectrofotomrtry) pada panjang gelombang 283,3 nm untuk Timbal $(\mathrm{Pb})$ dan 228,8 nm untuk Kadmium (Cd). . Hasil yang didapat dari AAS berupa nilai absorbansi yang kemudian dilakukan perhitungan untuk memperoleh kandungan Timbal yang sesungguhnya dari sampel. 8. Absorban hasil pengukuran contoh dimasukkan ke dalam persamaan regresi linier sehingga dipero- 
leh konsentrasi sampel melalui perhitungan dengan persamaan:

$[C d]=\frac{(D-E) x F p x V}{W}$

dimana [Cd] adalah konsentrasi logam berat $(\mathrm{mg}=\mathrm{gr})$; D adalah konsentrasi contoh hasil pembacaan AAS (mg/l); E adalah konsentrasi blanko (mg/l); Fp adalah faktor pengenceran; V adalah volume akhir larutan contoh (1); dan W adalah berat contoh (gr).

\section{HASIL DAN PEMBAHASAN}

Hasil pengujian logam berat Timbal $(\mathrm{Pb})$ dan Kadmium (Cd) pada udang vaname menggunakan AAS dengan metode graphite furnace (Tabel 1). Kandungan Kadmium tertinggi yaitu pada sampel 4 sebesar 0,011 mg/kg dan kandungan Kadmium terendah pada sampel 6 yaitu sebesar $0,004 \mathrm{mg} / \mathrm{kg}$. Hasil pemeriksaan kandungan logam berat Kadmium (Cd) pada daging udang menggunakan standar uji CRM memperoleh nilai sebesar $0,282 \mathrm{mg} / \mathrm{kg}$.

Kandungan Cd tertinggi ditemukan pada sampel 4 sebesar $0,011 \mathrm{mg} / \mathrm{kg}$ dan kandungan $\mathrm{Cd}$ terendah ditemukan pada sampel 6 yaitu sebesar $0,004 \mathrm{mg} / \mathrm{kg}$. Berdasarkan hasil pengujian tersebut dapat disimpulkan bahwa kandungan logam berat Cd pada masing-masing sampel udang tergolong rendah menurut BPOM (batas maksimum Cd 0,1 mg/kg), World Health Organization (WHO) (batas maksimum $\mathrm{Cd} 0,5 \mathrm{mg} / \mathrm{kg}$ ), dan UNI EROPA (batas maksimum Cd $2 \mathrm{mg} / \mathrm{kg}$ ). Oleh karena itu, sampel udang tersebut masih aman untuk dikonsumsi dan dapat menjadi komoditi ekspor.

Kandungan Timbal tertinggi yaitu pada sampel 3 sebesar $0,019 \mathrm{mg} / \mathrm{kg}$ dan kandungan Timbal terendah pada sampel 5 yaitu sebesar $0,003 \mathrm{mg} / \mathrm{kg}$. Hasil pemeriksaan kandungan logam berat Timbal $(\mathrm{Pb})$ pada daging udang menggunakan standar uji CRM memperoleh nilai sebesar $0,411 \mathrm{mg} / \mathrm{kg}$ (Tabel 2).

Kandungan $\mathrm{Pb}$ tertinggi ditemukan pada sampel 3 yaitu sebesar $0,019 \mathrm{mg} / \mathrm{kg}$ dan kandungan $\mathrm{Pb}$ terendah ditemukan pada sampel 5 yaitu sebesar 0,003 $\mathrm{mg} / \mathrm{kg}$. Berdasarkan hasil pengujian tersebut dapat disimpulkan bahwa kandungan logam berat $\mathrm{Pb}$ menurut BPOM pada masing-masing sampel udang tergolong rendah (batas maksimum $\mathrm{Pb} 0,2$ $\mathrm{mg} / \mathrm{kg}$ ), World Health Organization (WHO) (batas maksimum $\mathrm{Pb} 0,5 \mathrm{mg} / \mathrm{kg}$ ), dan UNI EROPA (batas maksimum $\mathrm{Pb} 2$ $\mathrm{mg} / \mathrm{kg}$ ). Oleh karena itu, sampel udang tersebut masih aman untuk dikonsumsi dan dapat menjadi komoditi ekspor.

Logam berat adalah unsur logam yang mempunyai densitas lebih besar dari 5 $\mathrm{gr} / \mathrm{cm} 3$. Berbeda dengan logam biasa, logam berat biasanya menimbulkan efekefek khusus pada mahkluk hidup. Dapat dikatakan bahwa semua logam berat dapat menjadi racun yang akan meracuni tubuh mahkluk hidup jika terkonsumsi terlalu banyak. Hal ini sesuai dengan Widyastuti (2002) yang menyatakan bahwa logam Timbal $(\mathrm{Pb})$ juga merupakan zat yang terbukti mampu menekan sistem imun sehingga terjadi penurunan jumlah sel penghasil antibodi.

Terdapatnya logam berat pada tubuh udang terjadi pada saat proses rantai makanan. Udang memakan bentos-bentos kecil yang merupakan hewan demersal yang mengambil material-material yang berbeda di dasar perairan sebagai sumber makanannya sehingga terjadi akumulasi logam berat pada tubuh udang. Hal 
Tabel 1 Hasil uji logam berat Kadmium $(\mathrm{Cd})$ pada udang vaname (Litopenaeus vannamei) dari beberapa pasar tradisional di Kota Medan

\begin{tabular}{ccccccc}
\hline Lokasi Sampel & Berat Sampel & Konsentrasi & CRM & Sertifikat & BPOM & WHO \\
\hline Pasar Padang Bulan & 5,060 & 0,007 & & & & \\
Pasar Belawan & 5,043 & 0,009 & & & & \\
Pasar Merah & 5,024 & 0,009 & 0,411 & $0,404 \pm 0,062$ & 0,1 & 0.5 \\
Pasar Pancing & 5,011 & 0,011 & & & \\
Pasar Petisah & 5,044 & 0,009 & & & \\
Pasar Sei Kambing & 5,039 & 0,004 & & & \\
\hline
\end{tabular}

Tabel 2 Hasil uji logam berat Timbal $(\mathrm{Pb})$ pada udang vaname (Litopenaeus vannamei) dari beberapa pasar tradisional di Kota Medan

\begin{tabular}{ccccccc}
\hline Lokasi Sampel & Berat Sampel & Konsentrasi & CRM & Sertifikat & BPOM & WHO \\
\hline Pasar Padang Bulan & 5,060 & 0,006 & & & & \\
Pasar Belawan & 5,043 & 0,008 & & & \\
Pasar Merah & 5,024 & 0,019 & 0,411 & $0,404 \pm 0,062$ & 0,2 & 0,5 \\
Pasar Pancing & 5,011 & 0,013 & & & \\
Pasar Petisah & 5,044 & 0,003 & & & \\
Pasar Sei Kambing & 5,039 & 0,009 & & & \\
\hline
\end{tabular}

ini sesuai dengan Tumisem and Puspawiningtiyas (2011) yang menyatakan bahwa makanan udang adalah $85 \%$ krustasea (kepiting kecil dan udang kecil) dan moluska, sedangkan $15 \%$ terdiiri dari annelida dan lainnya. Krustasea termasuk dalam organisme perairan yang bersifat demersal sehingga sebagian hidupnya berada di dasar perairan.

Sampel yang diteliti didekstruksi dengan pemijaran pada suhu $450^{\circ} \mathrm{C}$. Dekstruksi merupakan suatu cara untuk menghilangkan senyawa-senyawa yang ada di dalam sampel. Kemudian penambahan asam klorida pada abu yang diperoleh dari hasil pemijaran digunakan sebagai pelarut. Kelebihan asam dihilangkan dengan cara diuapkan melalui pemanasan kembali. Abu yang diperoleh kemudian dilarutkan dengan asam nitrat, dimaksudkan untuk menyempurnakan hilangnya senyawa-senyawa organik yang berada di dalam sampel. Setelah dilarutkan kemudian dipanaskan kembali dan dicukupkan volumenya dengan akuades dalam labu tentukur 50 $\mathrm{ml}$. Logam berat yang masuk ke dalam perairan dapat merubah struktur komu- nitas perairan, jaringan makanan, genetik, bentuk fisik, dan resistensi biota air. Logam berat dapat merusak stabilitas, keanekaragaman, dan kedewasaan ekosistem perairan. Tingkat kerusakan ekosistem atau kehancuran biota air oleh logam berat tidak sama tergantung jenis logam berat, tetapi kehancuran salah satunya akan memutus mata rantai makanan dan kehidupan yang ada di dalam ekosistem perairan. Diantara logam berat yang masuk ke dalam perairan, $\mathrm{Hg}, \mathrm{Cd}$ dan $\mathrm{Pb}$ sangat berbahaya karena dapat mengganggu fungsi normal enzim dan struktur seluler ikan dan biota air lainnya. Hal ini dikarenakan ketiga jenis logam berat tersebut mempunyai afinitas yang besar terhadap sulfihidril (-SH) yang merupakan gugus fungsi pada asam amino yang dapat mengikat logam berat.

Berdasarkan hasil uji laboratorium pada logam berat Kadmium (Cd) dan Timbal $(\mathrm{Pb})$ dengan AAS metode graphite furnace diketahui nilai kandungan $\mathrm{Cd}$ tertinggi adalah pada sampel 4 yaitu senilai $0,011 \mathrm{mg} / \mathrm{kg}$, dan yang terendah adalah pada sampel 6 yaitu senilai $0,004 \mathrm{mg} / \mathrm{kg}$. Kandungan $\mathrm{Pb}$ tertinggi 
terdapat pada sampel 3 senilai 0,019 $\mathrm{mg} / \mathrm{kg}$ dan nilai terendah adalah sampel 5 senilai $0,006 \mathrm{mg} / \mathrm{kg}$. Dari hasil pengujian tersebut dapat disimpulkan bahwa kandungan logam berat $\mathrm{Cd}$ dan $\mathrm{Pb}$ pada masing-masing sampel udang vaname tergolong masih rendah menurut (WHO) dan UNI EROPA.

Dalam memfasilitasi pengujian yang akurat dari keseluruhan sistem pengujian selama pengembangan atau penerapan suatu bahan uji menggunakan AAS metode graphite furnace pada Timbal $(\mathrm{Pb})$ dan Kadmium $(\mathrm{Cd})$ digunakanlah Certified Reference Material (CRM). Certified reference material adalah bahan atau zat yang memiliki sifat-sifat tertentu yang cukup homogen, stabil, dan telah diberi sertifikat dengan suatu prosedur teknis yang baku ditetapkan untuk dapat digunakan dalam pengukuran atau dalam pengujian dengan peranan yang penting dalam memvalidasi akurasi data.

CRM adalah tepung ikan yang telah diuji dan diakui keakuratannya sehingga dapat dijadikan sebagai standar dalam pengukuran logam berat. Hasil uji logam berat Kadmium (Cd) dan Timbal $(\mathrm{Pb})$ pada sampel yang diamati diketahui masih berada pada kisaran nilai CRM (kisaran nilai CRM Cd dan $\mathrm{Pb}$ berturut-turut adalah 0,299 $\pm 0,018$ $\mathrm{mg} / \mathrm{kg}$ dan $0,404 \pm 0,062 \mathrm{mg} / \mathrm{kg}$ ) sedangkan kandungan logam berat $\mathrm{Cd}$ tertinggi pada udang sampel adalah 0,011 $\mathrm{mg} / \mathrm{kg}$ udang dan kandungan logam berat $\mathrm{Pb}$ tertinggi pada sampel adalah senilai $0,019 \mathrm{mg} / \mathrm{kg}$ udang. Maka dapat dikatakan bahwa semua sampel udang tersebut masih aman untuk dikonsumsi oleh masyarakat.

\section{SIMPULAN}

Hasil uji logam berat cadmium (Cd) dan timbal $(\mathrm{Pb})$ diketahui masih berada pada kisaran nilai CRM. Konsentrasi $\mathrm{Pb}$ dan $\mathrm{Cd}$ yang ditemukan juga berada di bawah baku mutu BPOM dan World Health Organization (WHO). Oleh sebab itu sampel udang yang dijual masih dapat dikonsumsi dan dapat menjadi komoditi ekspor.

\section{Pustaka}

BSN (2001). Cara Uji Kimia Bagian 5tentang Penentuan Kadar Logam Berat Timbal $(\mathrm{Pb})$ dan Kadmium (Cd) pada Produk Perikanan. Badan Standarisasi Nasional (BSN), Jakarta.

Darmono (2006). Lingkungan hidup dan pencemaran: hubungannya dengan toksikologi senyawa logam. Universitas Indonesia.

Octavianus, R., Kartika, R., and Hindryawati, N. (2017). Analisis kadar logam pb, mn dan kandungan protein pada daging udang windu (penaeus sp.) yang diambil di perairan sungai dondang kecamatan muara jawa. In PROSIDING SEMINAR KIMIA, pages 85-93.

Palar, H. (1994). Pencemaran dan toksikologi logam berat. Jakarta: Rineka Cipta, 148.

Pardi, A., Raza'I, T., and Viruly, L. (2014). Kandungan logam berat timbal (pb) pada udang putih (penaeus merguiensis) berdasarkan tempat penangkapan nelayan di teluk tanjungpinang kepulauan riau. Jurnal Universitas Maritim Raja Ali Haji.

Salbiah, Putra, E. D., and Aman, C. (2009). Analisis logam pb, cd, cu, 
dan zn dalam ketam batu, dan lokan segar yang berasal dari perairan belawan secara spektrofotometri serapan atom. Majalah Kedokteran $\mathrm{Nu}$ santara, 1(1):20-25.

Sasongko, A., Yulianto, K., and Sarastri, D. (2017). Verifikasi metode penentuan logam kadmium (cd) dalam air limbah domestik dengan metode spektrofotometri serapan atom. JST (Jurnal Sains dan Teknologi), 6(2):228-237.

Supriadi, S. (2016). Analisi Kadar Logam Berat Timbal $(\mathrm{Pb})$, Kadmium (Cd) dan Merkuri ( $\mathrm{Hg}$ ) Pada Wisata Pantai Akkarena dan Tanjung Bayang Makassar. PhD thesis, Univeritas Islam Negeri Alauddin Makassar.

Tumisem, T. and Puspawiningtiyas, E. (2011). Analisis kadar logam dan cara mudah mengenali udang yang terakumulasi logam: Studi kasus tentang udang di sungai donan cilacap, jawa tengah (metal content analysis and easily recognize for shrimps that accumulates of metal: Case study about shrimps). Jurnal Manusia dan Lingkungan, 18(2):114-126.

Widajanti, L., Girsang, R., and Pradigdo, S. F. (2004). Studi keamanan pangan kimiawi dari logam berat timbal pada euthynnus sp, di perairan semarang. Jurnal Kesehatan Lingkungan Indonesia, 3(2):66-68.

Widyastuti, P. (2002). Bahaya bahan kimia pada kesehatan manusia dan lingkungan. Penerbit Buku Kedokteran EGC. Jakarta. 
